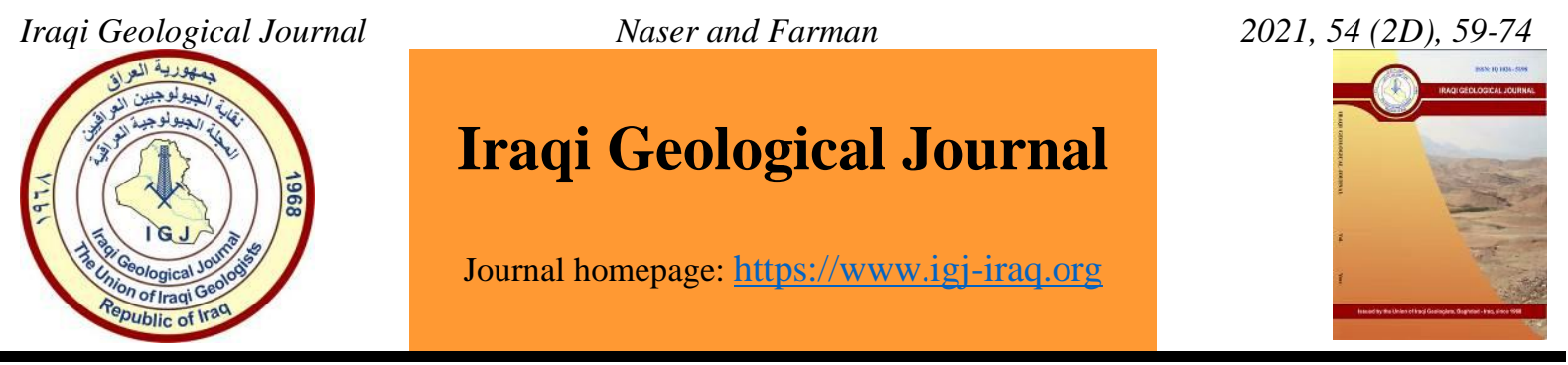

\title{
Optimizing Water Injection Performance by Using Sector Modeling of the Mishrif Formation in West Qurna-1 Oil Field, Southern Iraq
}

\author{
Sajjad Jameel Naser ${ }^{1, ~ *}$ and Ghanim M. Farman ${ }^{2}$ \\ 1 Basra Oil Company, Basra, Iraq \\ 2 Department of Petroleum Engineering, College of Engineering, University of Baghdad \\ * Correspondence: sajadalyasery@gmail.com
}

Received: 22 June 2021; Accepted: 27 July 2021; Published: 31 October 2021

\begin{abstract}
The regular job of a reservoir engineer is to put a development plan to increase hydrocarbon production as possible and within economic and technical considerations. The development strategy for the giant reservoir is a complex and challenging task through the decision-making analysis process. Due to the limited surface water treatment facility, the reservoir management team focuses on minimizing water cut as low as possible by check the flow of formation and injected water movement through the Mishrif reservoir. In this research, a representative sector was used to make the review of water injection configuration, which is considered an efficient tool to make study in a particular area of the entire field when compared with the full-field model on the basis of time-consuming and computational analysis. The sector model was neighboring by extra grid blocks and three pseudo wells as injector wells to realize the pressure on the sector boundary, which attained an acceptable history matching. The fluid model and physics model were introduced by using Pressure Volume Temperature data of well involved in the study area and two relative permeability curves. Fourteen wells were utilized in this work, four wells are injectors, and the rest are producer. The development scenarios were implemented by setting various targets of oil production and different water injection rates required for pressure maintenance operations. Optimization of water cut has been applied by adjustment of production and injection rates and shut off the high water cut intervals. The results obtained from this study showed that the inverted 9-spot has a good recovery which is illustrated in the case_2C, the production rate was $(49,000 \mathrm{STB} / \mathrm{D})$ with minimum water cut $(27.5 \%)$ as compared with a five-spot pattern.
\end{abstract}

Keywords: Mishrif Formation; Sector modeling; West Qurna-1 oilfield; Water injection; Optimizing performance

\section{Introduction}

The main purpose of reservoir modeling is that reservoir modeling is the most powerful available predictive tool for oilfield development, which engages geological and reservoir information more than any else predicting tool of reservoir performance (Chen, 2007). The strategy of developing large-scale reservoirs is a complicated and challenging decision-making process in the analysis process. For example, these formations are considered to contain a large number of wells with long production history, in addition to heterogeneity characteristics that require the use of models to increase the computational requirements (Tleukhabyluly et al., 2016).

DOI: $10.46717 /$ igj.54.2D.5Ms-2021-10-24 
There are several approaches to make the computational requirement less through using an approach by dividing the interesting area into several smaller sectors with specific dynamic models and simulation these sectors do not depend on one another. A sector modeling has been defined by several authors, such as Dzyuba et al., (2012) Bruijnzeels and O'Halloran, (1995). Sector modeling recently became a more efficient approach to make an evaluation of water injection performance in a particular area, which provides a shorter time when compared with a full-field model as time-consuming. Dynamic boundary conditions of the sector relate to the parameters that should be updated periodically to consider the influence of adjacent sectors; one treatment is to utilize pseudo wells (virtual wells) (Avansi et al., 2016). After the primary stage has reached its economic limits as a result of production and leads to pressure declines, the secondary stage is initiated to maintain the pressure and avoid reducing oil recovery.

Water flooding is the most frequent method used as a secondary recovery through injected water from a particular source such as (produced water, sea treated water, and river water), and works as water drive to sweep oil from injector to producer (Awadh et al., 2018a; Guyaguler and Horne, 2000; Boschetti et al., 2020). The simulation model outputs precision is impacted by time steps and grids number (Mattax and Dalton, 1990). The petrophysical heterogeneity in the Mishrif Formation units is related to changes of properties of porosity, water saturation and volume of fluid (Awadh et al., 2018b; Al-Mimar et al., 2018; Al-Mimar et al., 2019; Abbas and Mahdi, 2020). Optimizing reservoir development requires combining quantitative analysis of geological and geophysical with proper flow models to evaluate different development and completion options and relevant values of economic. Optimal development solutions are critical to maximizing the benefits of oil and gas production (Pan and Horne, 1998). The objective is to make an assessment of water injection modification and their feasibility by using a sector model rather than a full-field model to make a full analysis of possible decision making through proposed several configurations with several attempts in the production and injection profiles rates based on the optimization water cut rules such as workover operations(Ogbeiwi et al. 2018).

\section{Study Area}

West Qurna oil field is classified as one of giant's world reservoir. It is divided into two phases, West Qurna1 and West Qurna-1 oil field. West Qurna-1 oil field, which included in this study, has discovered and drilled the first well was (WQ1) in 1973. It is located about $50 \mathrm{~km}$ northwest of Basra city in south-eastern Iraq as shown in Fig. 1. In the West Qurna-1 oil field located in the hydrocarbon Province of Mesopotamia during the cretaceous period, several hydrocarbon areas were discovered in this field(Abdullah and Al-Shahwan, 2021). They are from highest to lowest in depth: (Yamama, Zubair, Mauddud, Mishrif, Khasib, and Sadi) (Abdullah et al., 2018). The main productive reservoir in this field is the Mishrif Formation which has been divided into six zones mA, CRI, mB1, CRII, mB2, and mC. The Mishrif Formation is stratigraphy bounded by the Khasib Formation at the top and Rumaila formation at the bottom as shown in Fig. 3, the Mishrif Formation consists of the anticlinal fold with gentle dips (Aqrawi et al., 2013). The studied wells in the sector area as shown in Fig. 2.

\section{Materials and Methods}

Available data has been utilized to build a simulation sector model which used for optimizing water injection performance scenarios in the Mishrif Formation. The wells in the sector under study are illustrated in Fig. 2, and the available wells data are displayed in Table.1. This procedure has been adopted as follows steps. 


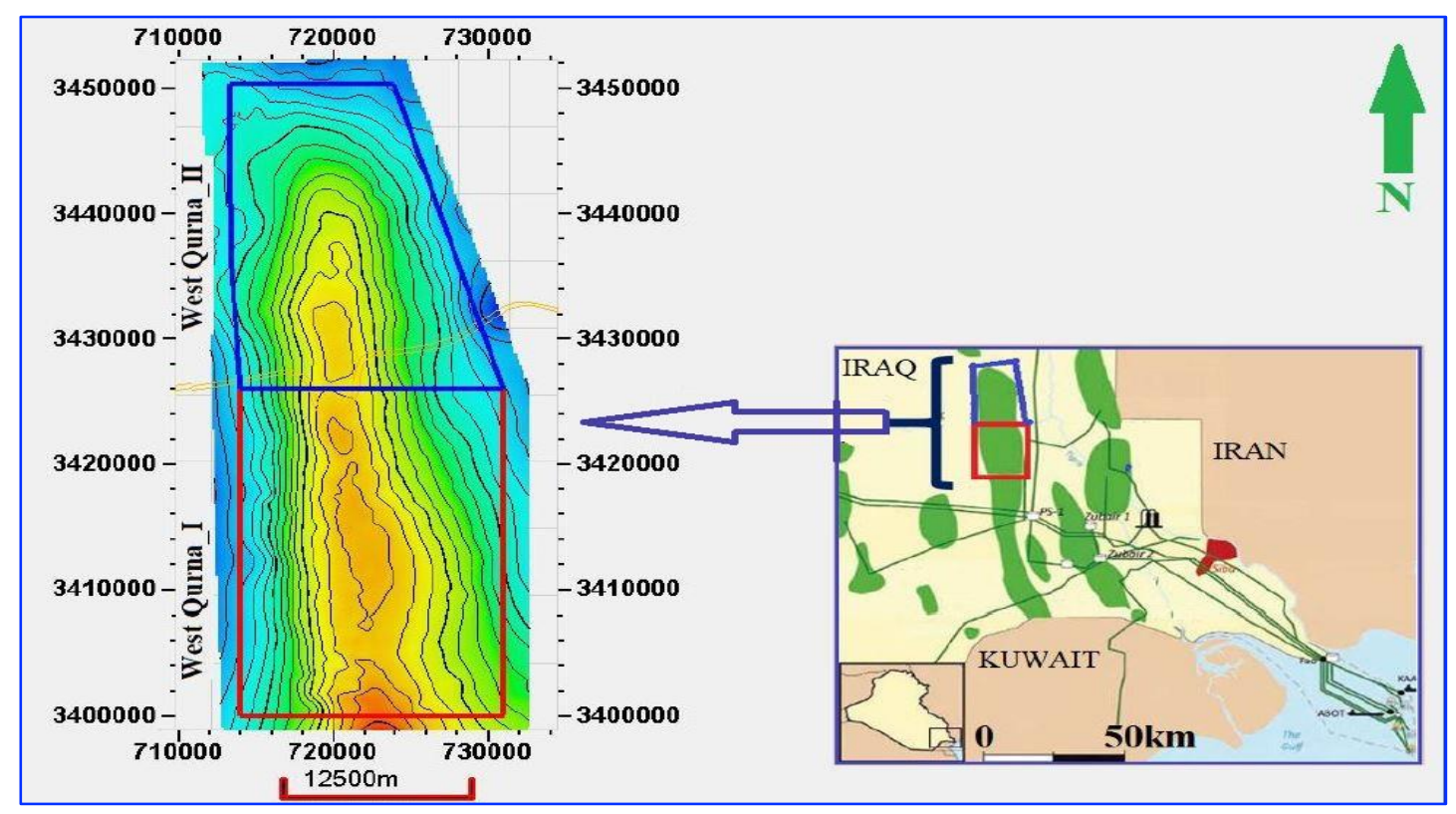

Fig. 1. Location map of studied area

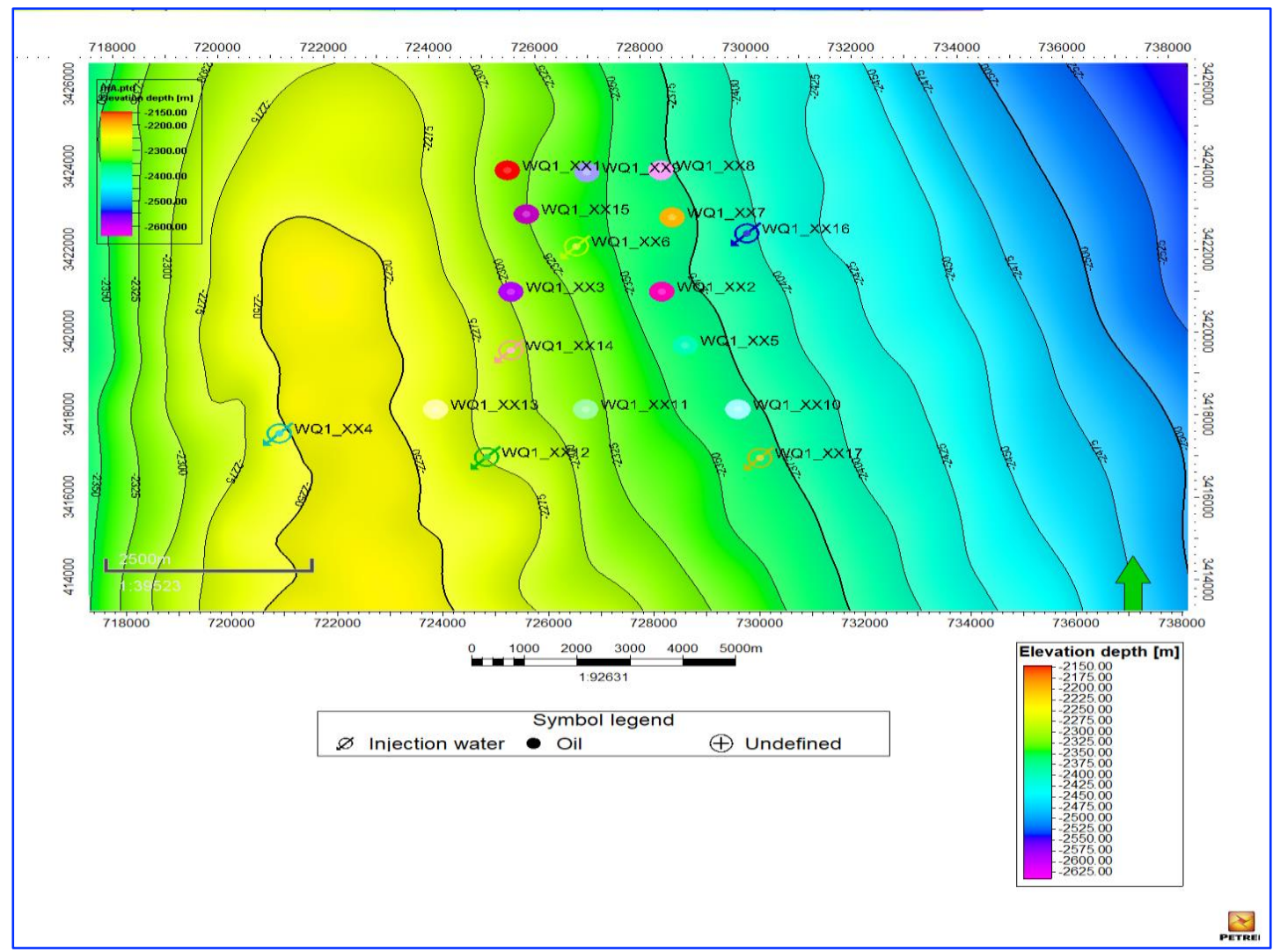

Fig. 2. Wells positions in the structural Mishrif Formation 


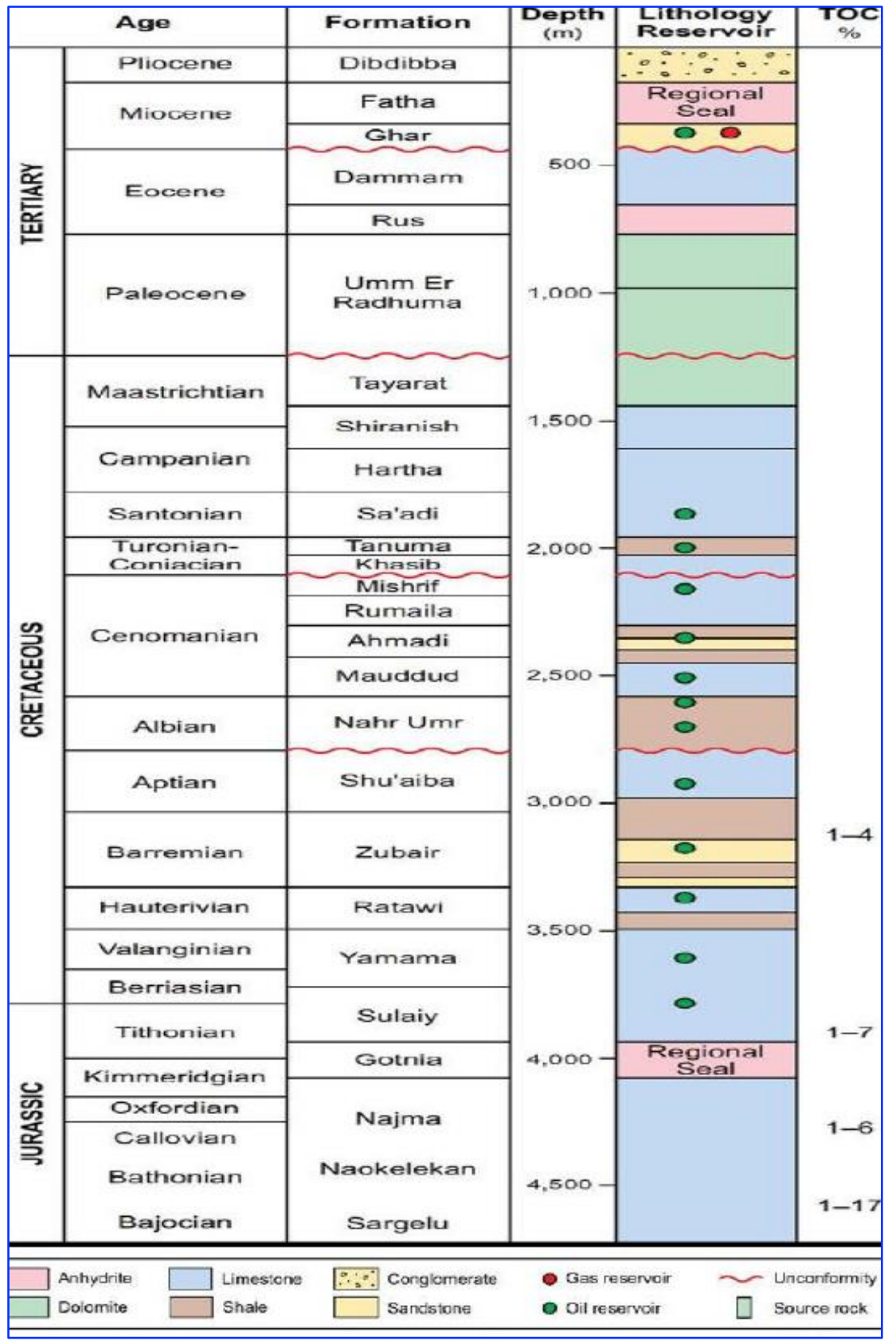

Fig. 3. Stratigraphy sequences of southern strata of Iraq

Table 1. Details of the actual wells used in the sector model

\begin{tabular}{clllccc}
\hline No. & Field & Well Name & Porosity & Water saturation & PVT & Core data \\
\hline 1 & WQ1 & WQ1_XX1 & AVL & AVL & & \\
2 & WQ1 & WQ1_XX2 & AVL & AVL & & \\
3 & WQ1 & WQ1_XX3 & AVL & AVL & & \\
4 & WQ1 & WQ1_XX5 & AVL & AVL & & \\
5 & WQ1 & WQ1_XX6 & AVL & AVL & & \\
6 & WQ1 & WQ1_XX7 & AVL & AVL & & \\
7 & WQ1 & WQ1_XX8 & AVL & AVL & & AVL \\
8 & WQ1 & WQ1_XX14 & AVL & AVL & AVL & \\
9 & WQ1 & WQ1_XX15 & AVL & AVL & AVL & \\
10 & WQ1 & WQ1_XX16 & AVL & AVL & & \\
\hline
\end{tabular}




\subsection{Permeability Prediction}

Permeability is considered one of the main properties of rock that dominates the flow moving through the porous media and resulted in control of water injection direction, which is favorable towards a good permeability region and leads to a good sweep efficiency(Ezekwe, 2010). In this study, the Mishrif reservoir of West Qurna-1 oil field has been adopted a hydraulic flow unit concept to estimate the permeability while the porosity obtained from Computer Processing Interpretation (CPI), and calibrated based on the core data after correction of shale content as displayed in CPI. Some of the equation has been adopted in this study. Based on the law of flow of porous media by Darcy's equation and the law of pipe flow by Poiseuille's law, Carman and Kozeny developed an empirical relationship for predicting permeability by modeling porous media as tube bundles of direct capillaries tube. Equations as follows:

$$
\mathrm{K}=\frac{\mathrm{r}^{2}}{8} * \emptyset \mathrm{e}
$$

The modified Carman-Kozeny equation.

$$
\mathrm{K}=\frac{\varnothing \mathrm{e}^{3}}{(1-\varnothing \mathrm{e})^{2}} \frac{1}{\mathrm{Fs \tau}^{2} \mathrm{Sgv}^{2}}
$$

Many attempts have been established to evaluate the permeability as a function of porosity, these attempts failed due to use the constant value of Kozeny constant $\left(F s \tau^{2}\right)$ and insufficient consideration of the term $\left(\mathrm{Sgv}^{2}\right)$. (Amaefule et al., 1993) has developed an important correlation for estimating permeability by dividing the equation. 2 by $(\varnothing \mathrm{e})$ and applying square root on the resulting equation as shown as below:

$$
\sqrt{\frac{\mathrm{K}}{\varnothing \mathrm{e}}}=\left(\frac{\emptyset \mathrm{e}}{1-\varnothing \mathrm{e}}\right)\left(\frac{1}{\sqrt{\mathrm{Fs} \mathrm{Sgv}^{2}}}\right)
$$

The left side of equation.1 representing reservoir quality index and resulted permeability in (md) as bellow.

$$
\begin{aligned}
& \mathrm{RQI}=0.0314 \sqrt[2]{\frac{\mathrm{K}}{\emptyset \mathrm{e}}} \\
& \varnothing \mathrm{z}=\frac{\emptyset \mathrm{e}}{(1-\emptyset \mathrm{e})}
\end{aligned}
$$

While the term $\left(\frac{1}{\sqrt{\mathrm{Fs} S \mathrm{~Sv}^{2}}}\right)$ is constituted by FZI as:

$$
\mathrm{FZI}=\left(\frac{1}{\sqrt{\mathrm{Fs} S g v^{2}}}\right)=\frac{\mathrm{RQI}}{\emptyset \mathrm{z}}
$$

These symbols are explained as below:

$\mathrm{K}$ and $\mathrm{r}$ : Permeability $\left(\mu \mathrm{m}^{2}\right)$, and pore radius $(\mathrm{cm})$.

Fs $\tau^{2}$ and Sgv: Kozeny constant from (5-100), and ratio of surface area to grain volume $\left(\mu \mathrm{m}^{-1}\right)$.

RQI: Reservoir Quality Index $(\mu \mathrm{m})$.

FZI: Flow Zone Indicator, and it's a function of both void ratio and Reservoir Quality Index.

$\emptyset \mathrm{e}$ and $\emptyset \mathrm{z}$ : Effective Porosity(fraction) and Normalized porosity as a fraction of pore volume to grain volume.

By taking the logarithm of both sides of equation (1), yields the flowing equation.

$$
\log (\mathrm{RQI})=\log (\varnothing \mathrm{z})+\log (\mathrm{FZI})
$$

And finally, form of equation applied for permeability prediction:

$$
\mathrm{K}=1014 * \mathrm{FZI}^{2} *\left[\frac{\emptyset \mathrm{e}^{3}}{(1-\varnothing \mathrm{e})^{2}}\right]
$$

According to equation 7 a straight line with a unit slope was obtained from plotting the log-log of RQI versus normalized porosity to describe the same flow characteristics on the same FZI values as shown in Fig. 5. All available core plugs data for the three wells were plotted and used to develop a basic correlation representative for the data and distribution hydraulic flow units. Fig. 4 displays the 


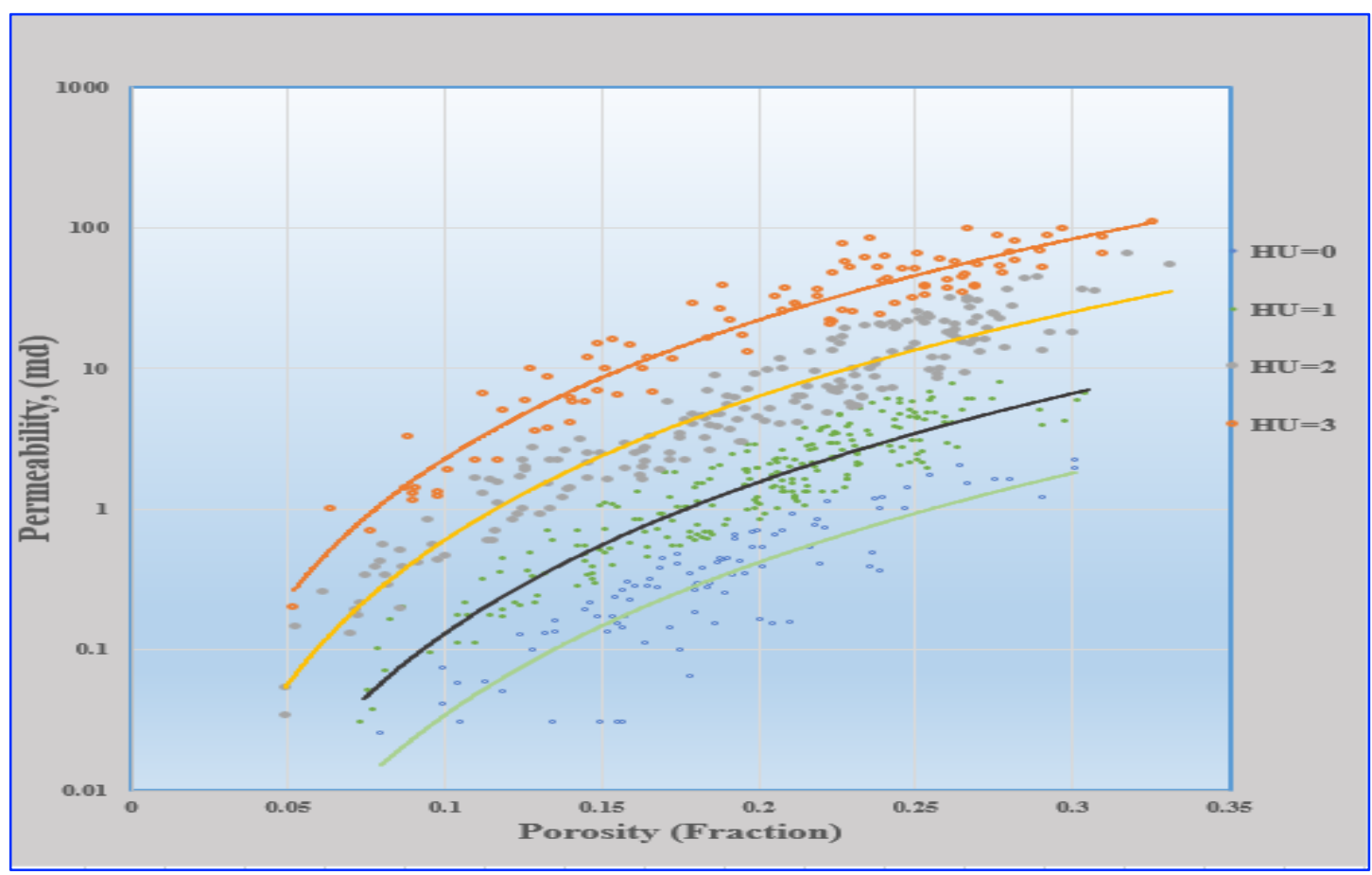

Fig. 4. Semi-log plot between porosity and permeability of core for relevant hydraulic unit

porosity-permeability relations for different HUs of the system, which show four groups of rock types in the Mishrif Formation. Fig.5 shows the cross plot of the log-log plot of RQI versus (Øz); this plot displays different hydraulic units based on different FZI values, where the first and second group represent poor to moderate quality of reservoir and the third and fourth group represent good to very good quality of the reservoir, such as porosity and permeability properties.

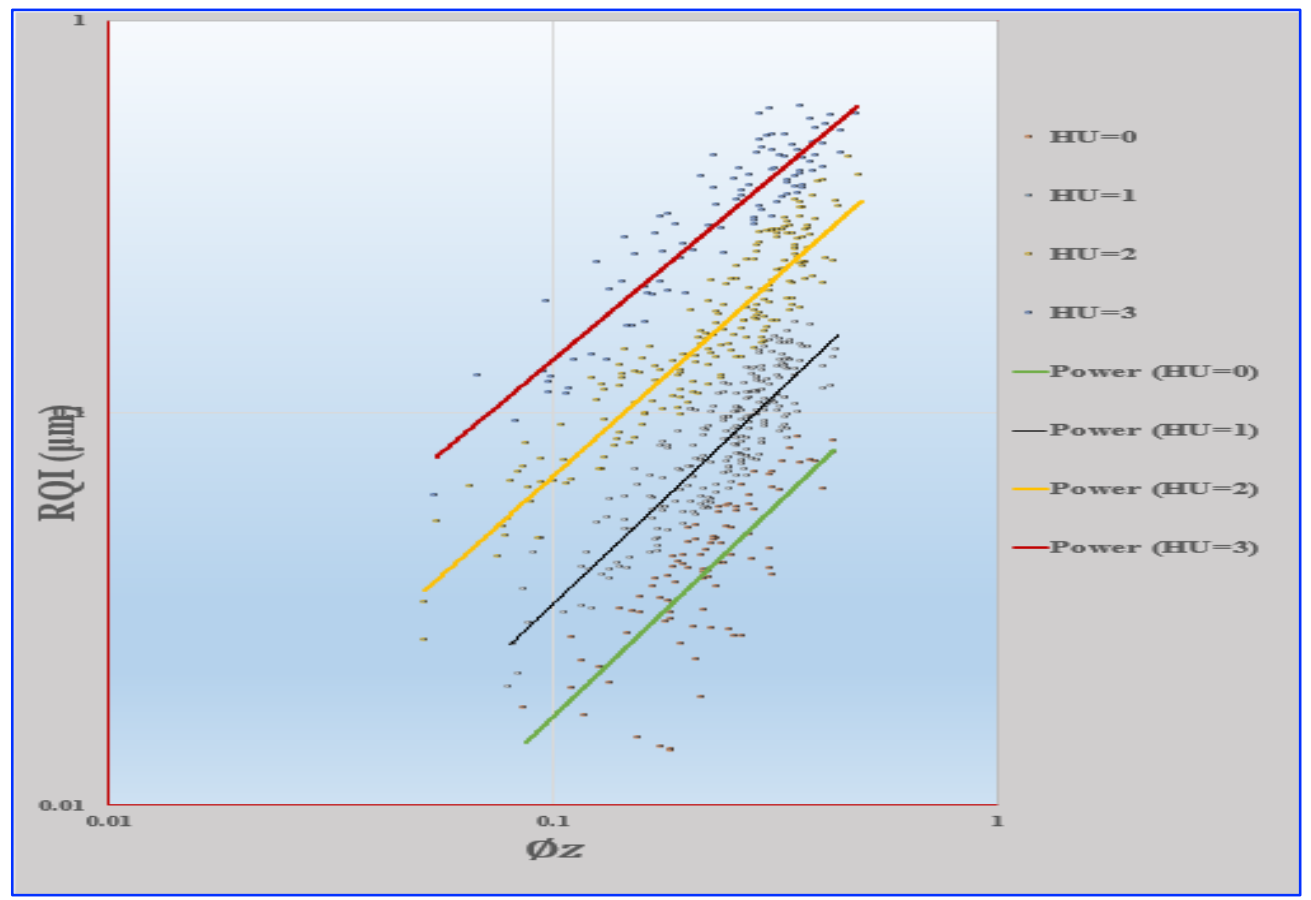

Fig. 5. Log-log cross plot of RQI X $\emptyset \mathrm{z}$ 
It is crucial to plot the probability of the Flow Zone Indicator (FZI), to emphasize the probability of boundaries of each type of rock obtained from the hydraulic units. This probability plot is the integral of the histogram plot that a normal distribution is represented in a straight-line format, (Fig. 6).

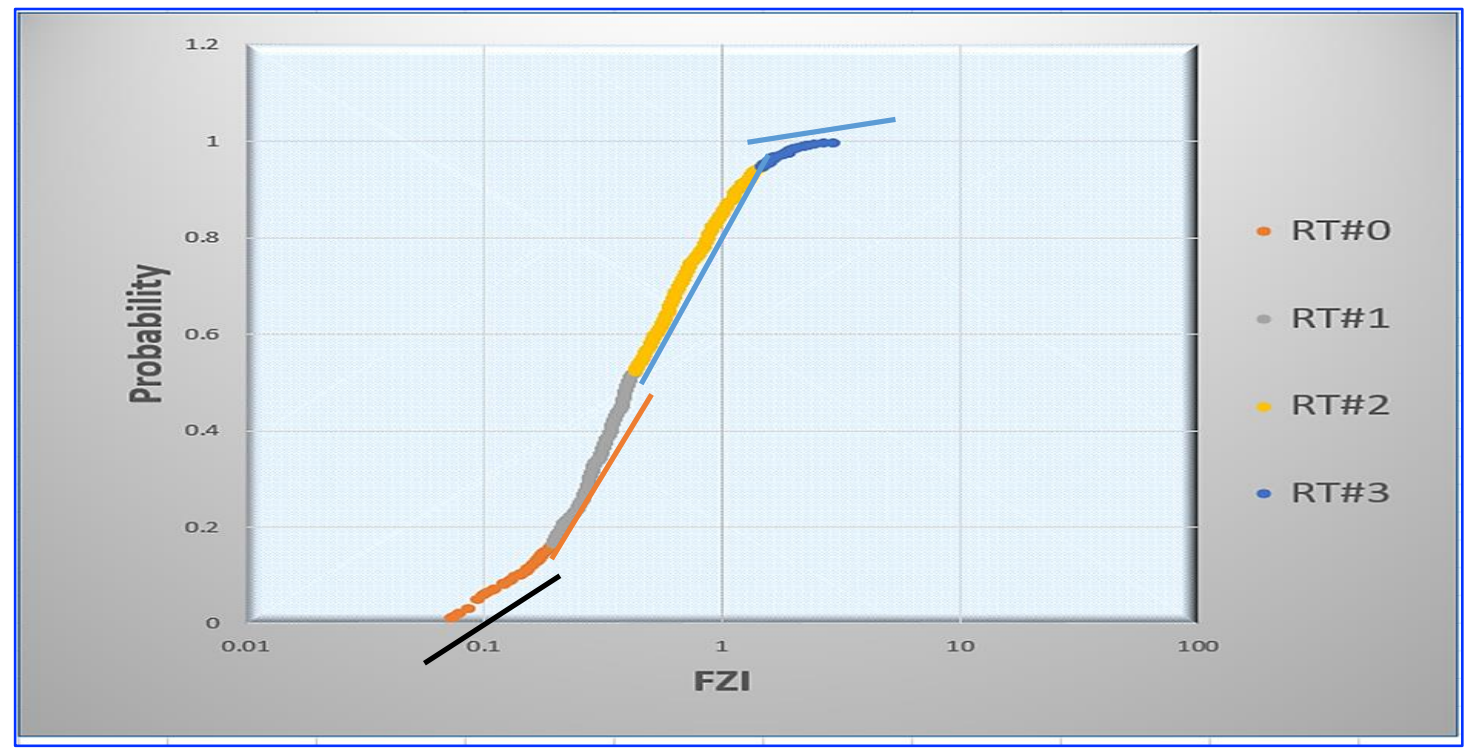

Fig.6. Normal probability of rock-types using FZI

\subsection{Initialization}

Usually, initialization of simulation models is required to introduce the capillary pressure data and relative permeability measurements. The trapped hydrocarbon and oil movement is controlled basically by the capillary pressure and the wettability, so it is important during the secondary operation recovery to specify the anticipated places where the oil is not extracted and fore mechanisms to put the efficient way for recovery operations(Hassler and Brunner, 1945). The available special core analysis (SCAL) is illustrated in Figs. 7 and 9. In this sector model, two relative permeability are imported to the model, which represents ( $\mathrm{mA} \& \mathrm{mB}$ ) respectively).

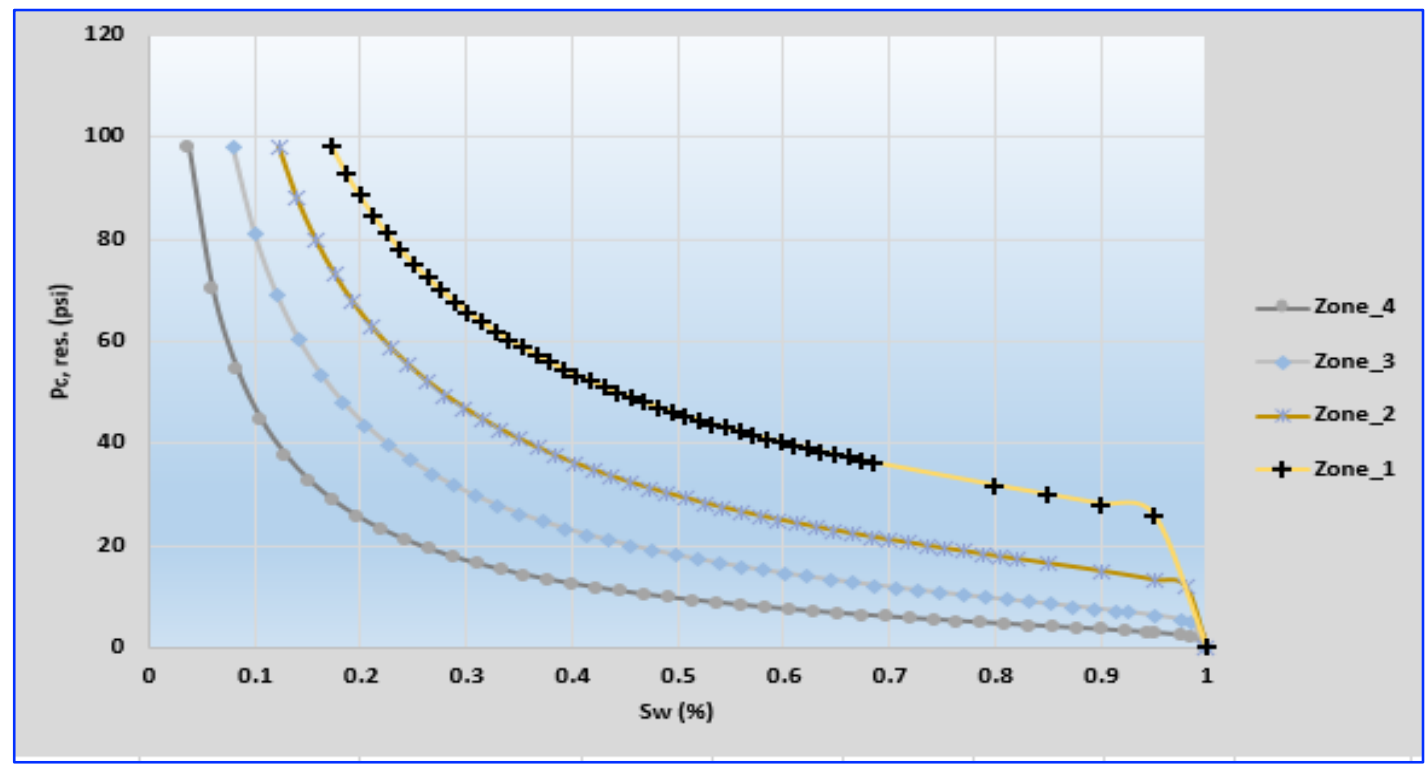

Fig. 7. Capillary pressure curve of the Mishrif Reservoir 


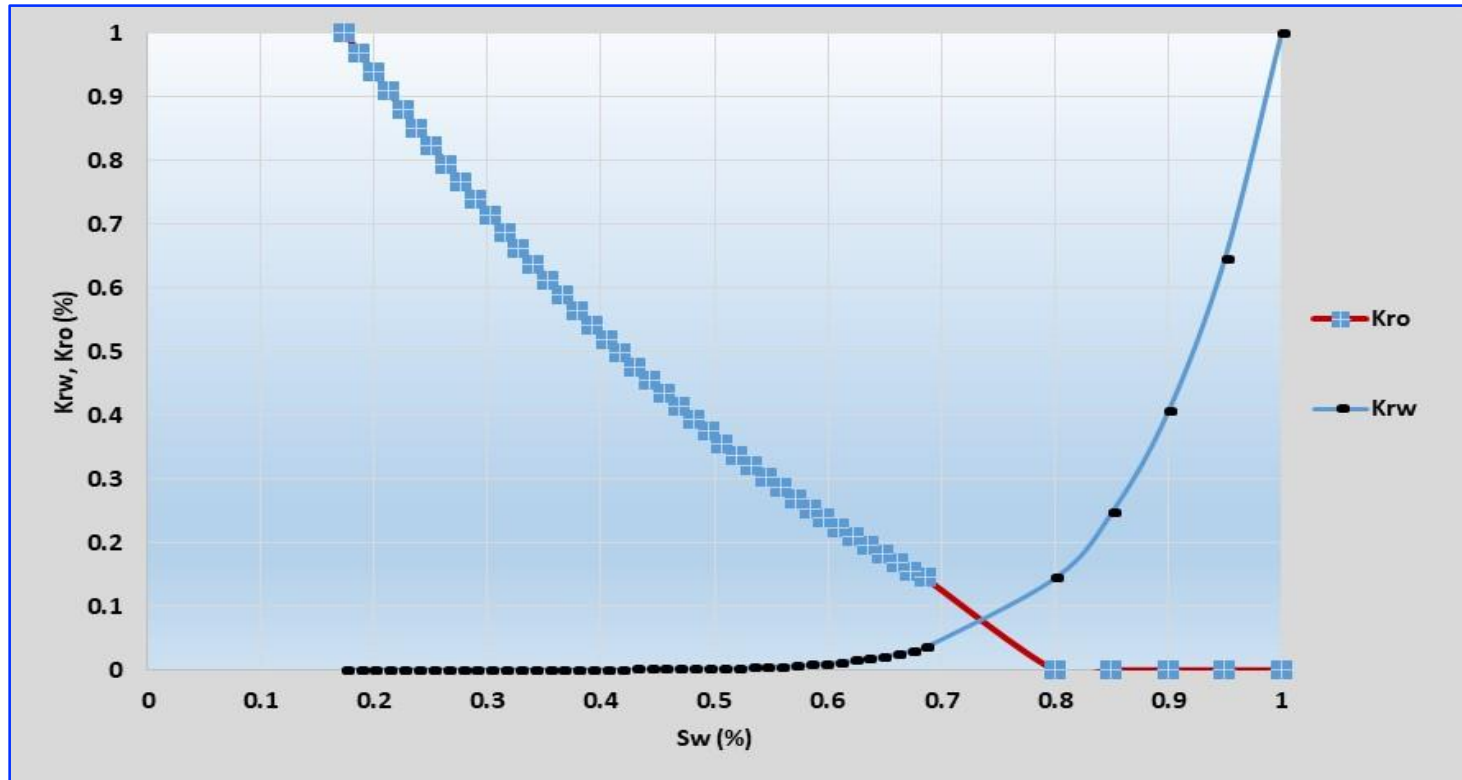

Fig. 8. Relative permeability for $\mathrm{mA}$ unit

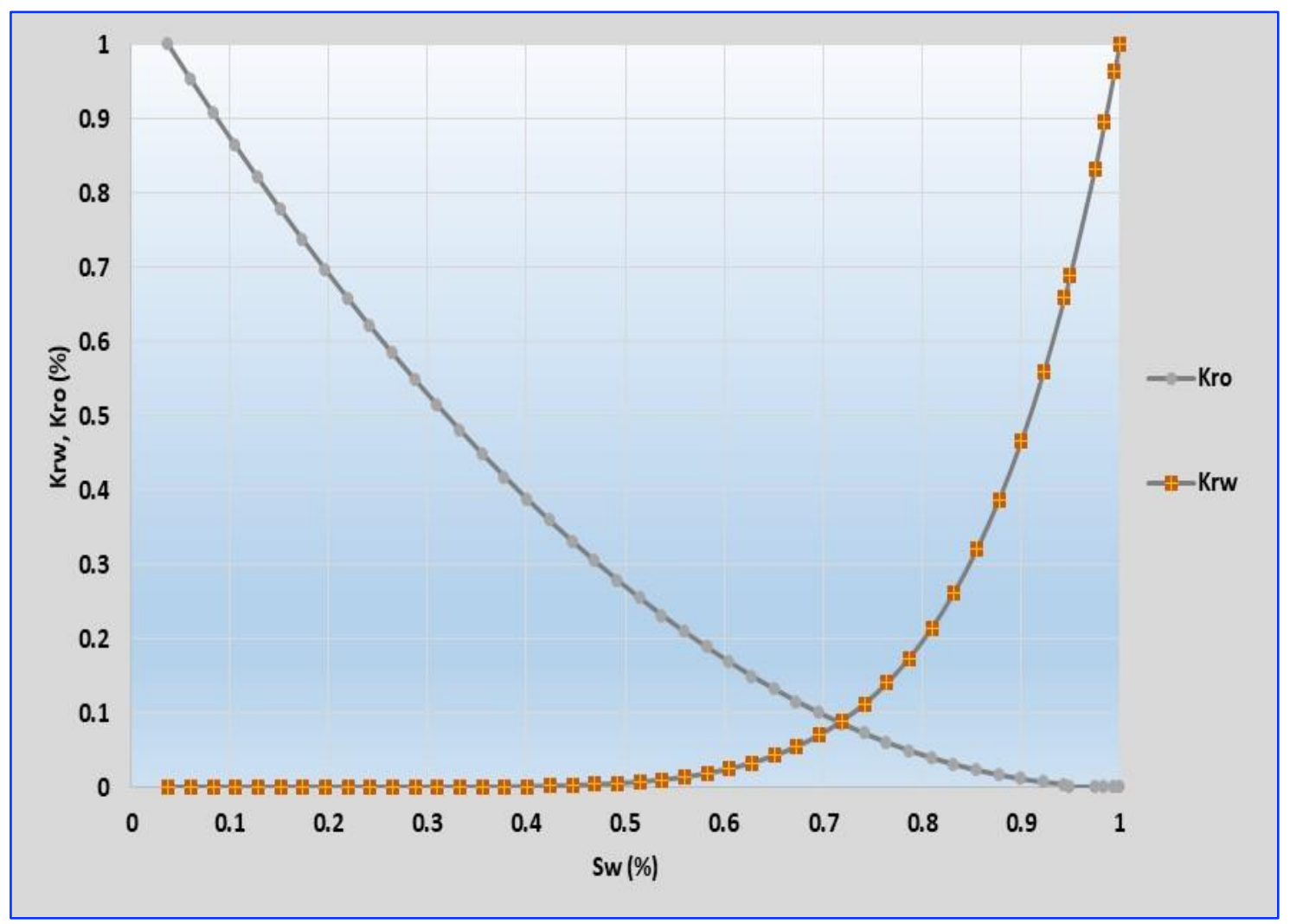

Fig. 9. Relative permeability curves for $\mathrm{mB}$ unit

\subsection{Water Saturation and Porosity Model}

The water saturation and porosity measurement have been obtained from the available open hole well logs analysis in Computer Processing Interpretation (CPI), and then distributed through geological model (static model). 


\subsection{Pressure-Volume-Temperature}

Mishrif reservoir West Qurna-1 oilfield is characterized as an understated reservoir, without any evidence of a gas cap originally in the reservoir under study. The initial reservoir pressure ( $\mathrm{Pi}$ ), formation temperature (T), GOR, and API are $3900 \mathrm{psi}, 181 \mathrm{~F}^{\circ}, 450$, and 23.7, respectively. The well WQ1-XX15 was involved in the sector area and used through the simulation model. The basic parameters of PVT analysis. PVT analysis of oil formation volume factor, Gas Oil Ratio (GOR), oil density, and oil viscosity of Mishrif Formation are illustrated in Figs. 10, 11, 12, and 13, respectively. The average oil density and average gas density for the Mishrif Formation are 6.9417 1b/gal, $6.4093 \mathrm{lb} / \mathrm{gal}$ respectively. The available average water properties of the Mishrif reservoir in West Qurna-1 oilfield are displayed in Table 2.

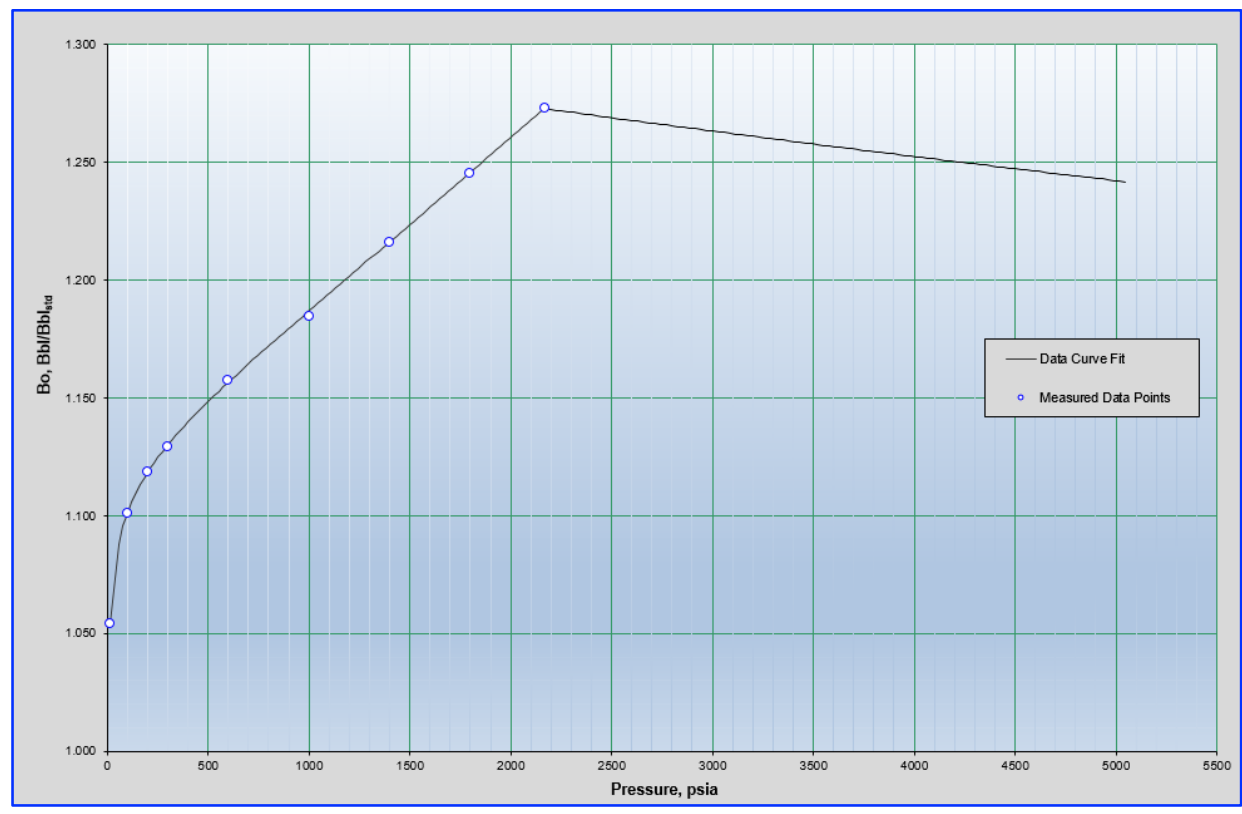

Fig. 10. Formation oil volume (Bo) versus pressure

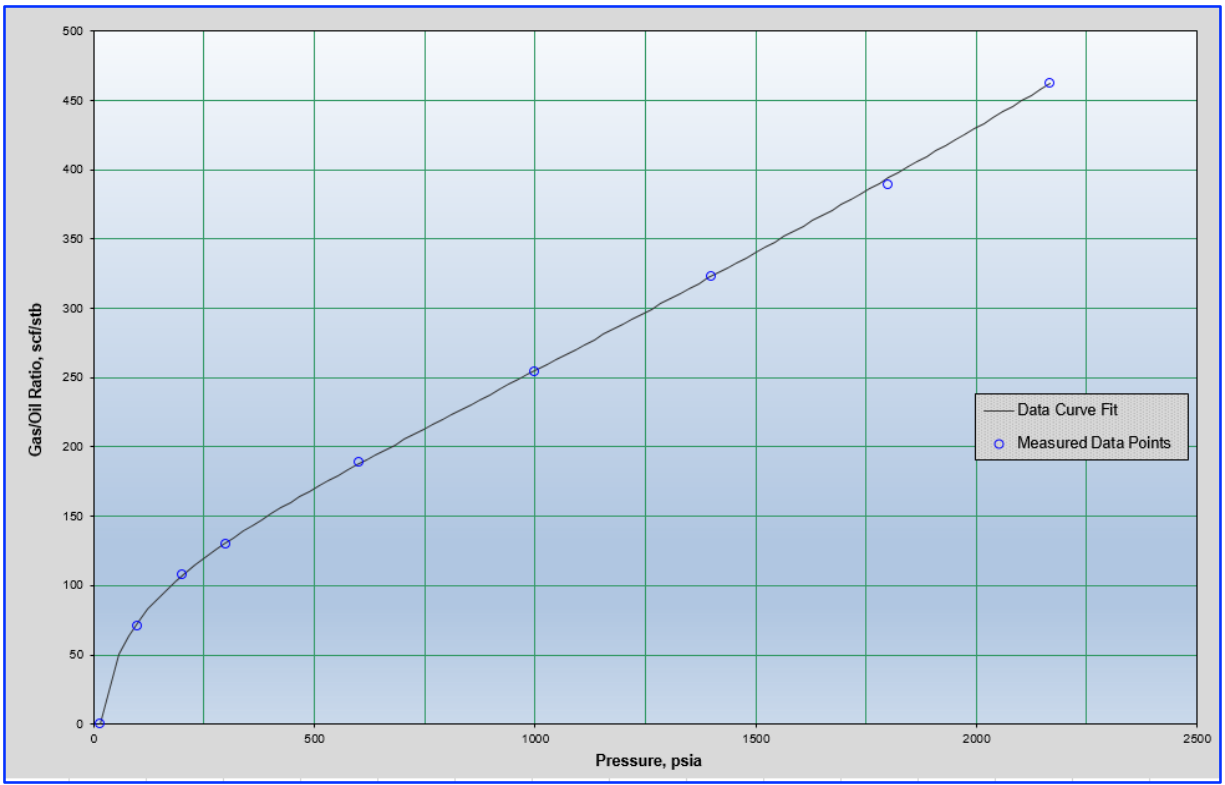

Fig. 11. Gas oil ratio versus pressure 


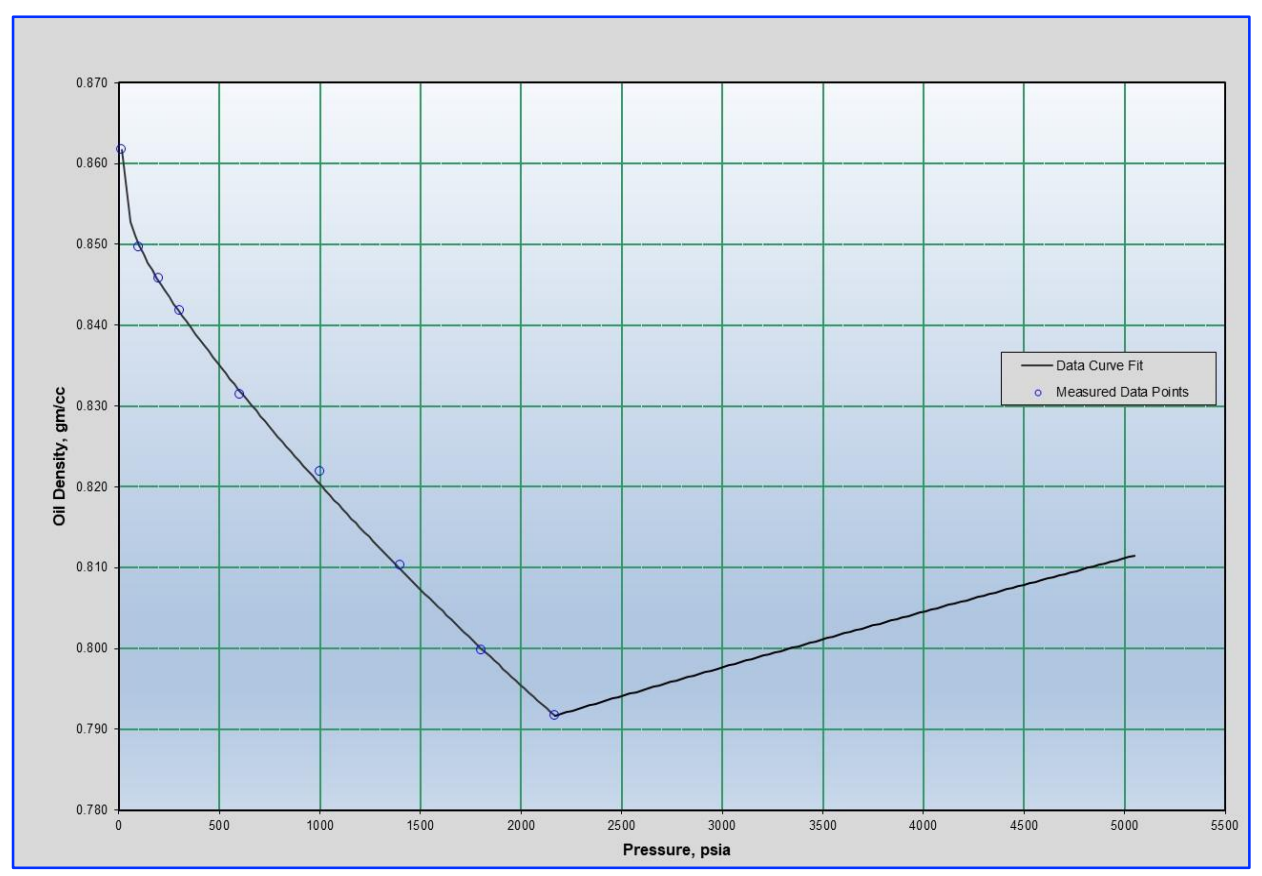

Fig. 12. Oil density versus pressure

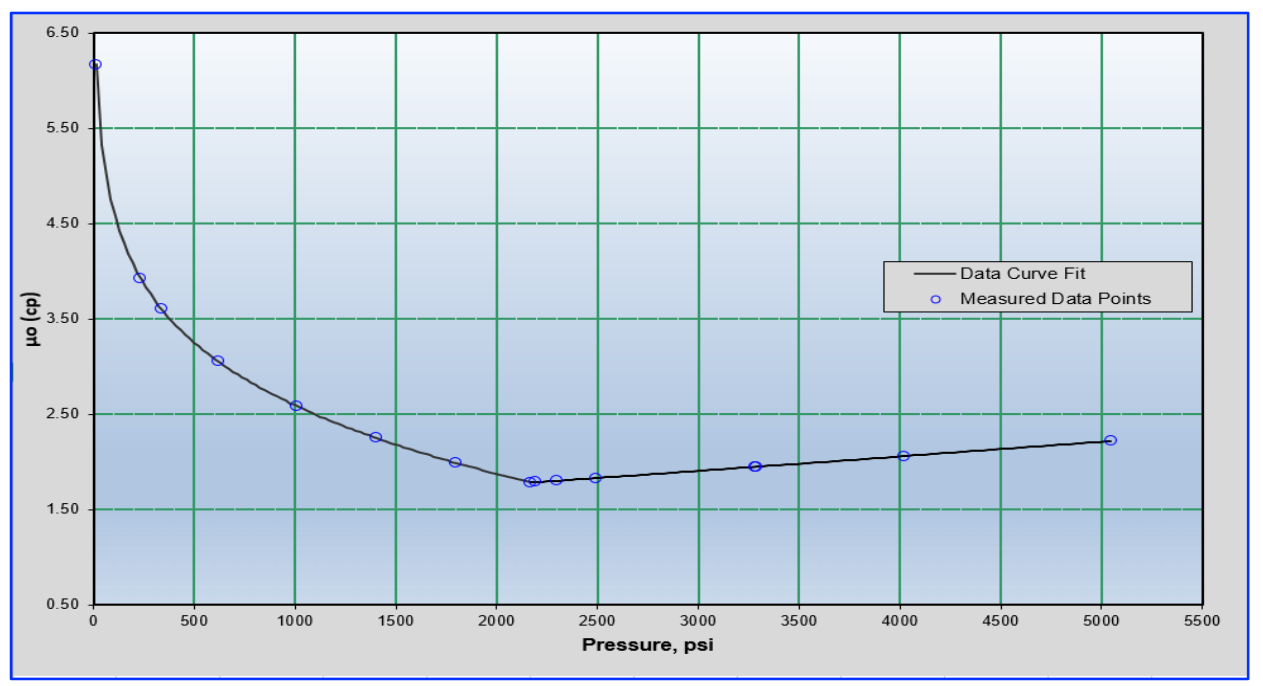

Fig. 13. Oil viscosity versus pressure

Table 2. Average water properties of the Mishrif Formation

\begin{tabular}{lc}
\hline Property (Unit) & Average value \\
\hline Water formation volume factor (RB/STB) & 1.087 \\
Water salinity $(\mathrm{ppm})$ & 180,000 \\
Water density $(\mathrm{g} / \mathrm{cm} 3)$ & 1.1563 \\
Water viscosity $(\mathrm{cp})$ & 0.596 \\
PH & 5.6 \\
Total dissolved Solids (TDS), $(\mathrm{ppm})$ & 220 \\
\hline
\end{tabular}




\subsection{Geological and Reservoir Modeling}

The geological model is a process that implies steps for building structural and stratigraphy of the interested reservoir based on core data analysis and interpretation. The characterization operation through the geological model is essential to reduce uncertainty calculation which is performed in the Original Oil in Place (OOIP) and later in the reservoir model. Geological model construction compromised several steps, which include building 3-D for each zone in the reservoir depending on the available input data (wellhead, well tops, and contour map). Fig.11 illustrated the well location on the surface map. A three-dimensional geocellular model was built from the horizon model and specific studied area of the sector that contains the wells under study. Each grid cell has a specific property of porosity, permeability saturation, and production history, such as flow rates and pressure measurements. The grid dimension was used $250 \mathrm{~m}$ in X-direction and $250 \mathrm{~m}$ in Y-direction, and $85 \mathrm{~m}$ in Z-direction. This resulted in, gridding model represented in Fig.14, which shows three basic skeletons in the interested reservoir.

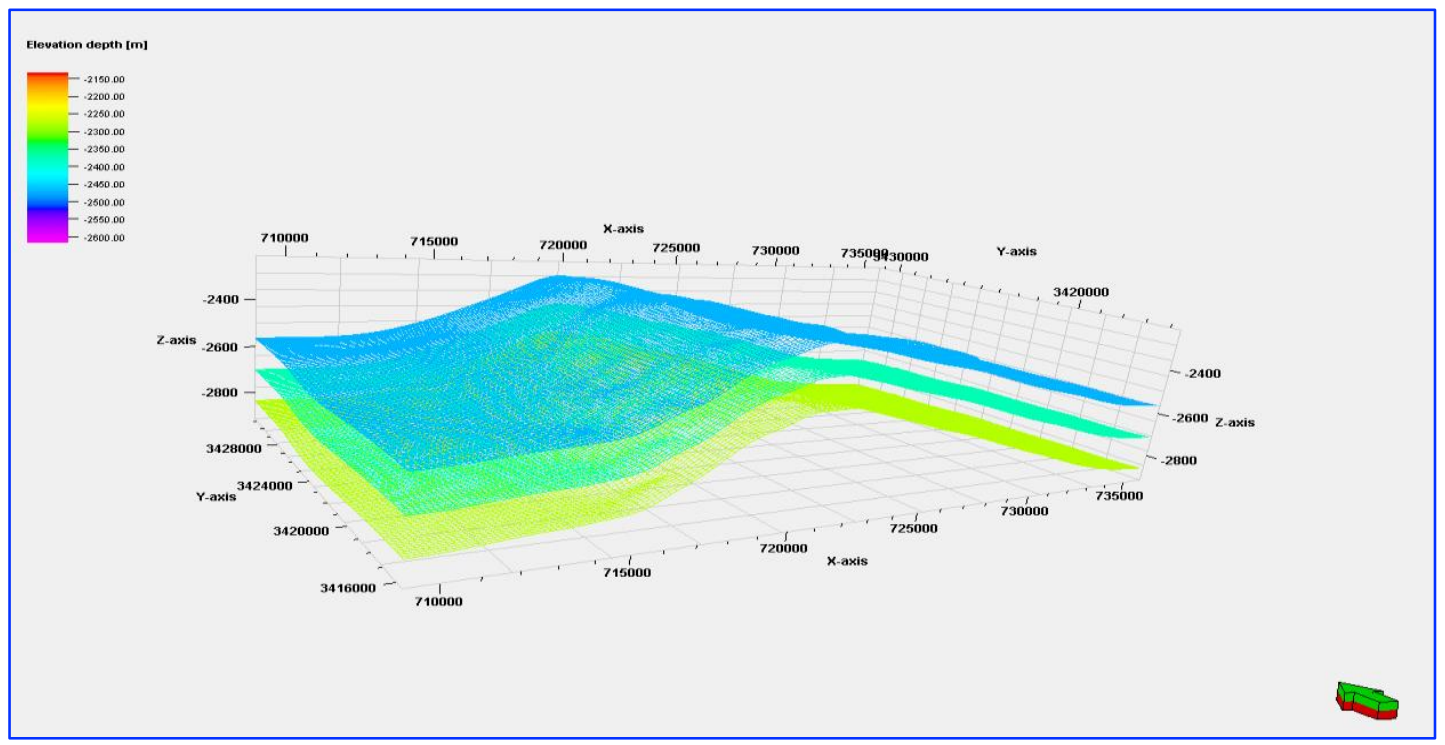

Fig. 14. Three main skelton of the sector area

The petrophysical properties were distributed through the geological model by using the Sequential Gaussian Simulation algorithm (SGS), as performed for all units in the Mishrif Formation through petrophysical modeling. Fig. 15 displays an illustration of the mA unit of porosity modeling (Lian et al., 2017).

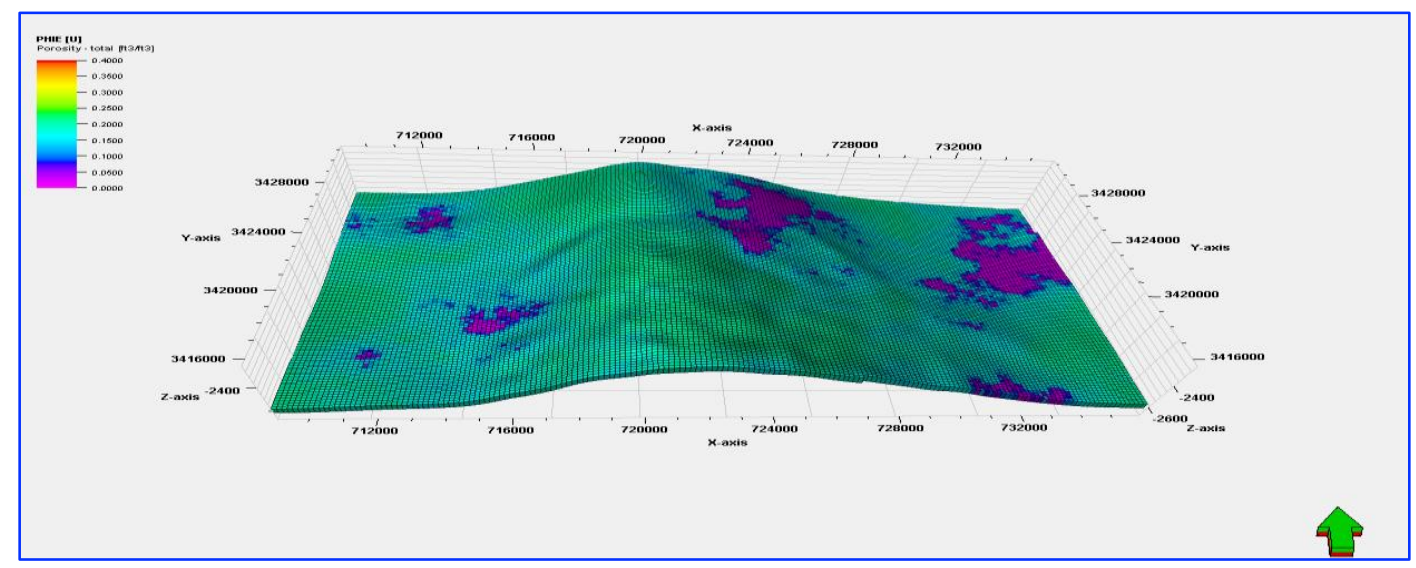

Fig. 15. mA porosity distribution of Mishrif reservoir 


\section{Results}

\subsection{Model Outputs}

In this section, it has been summarized the output approach of the simulator model and its constraints for prediction strategies.

\subsection{History Matching}

Generally, obtaining history matching of a reservoir model depends mainly on the basics of reservoir engineering, the quantity and quality of available data, the type of model, and study objectives:

- The geological model properties, which were constructed as shown previously, have been imported to the simulation model with the total number of grid cells 112770 grid blocks. Porosity and permeability have been earlier identified, and capillary pressure and relative permeability, PVT analysis of reservoir fluids which relates to the well WQ1-XX15, that is involving in the sector studied area, all these were identified to model.

- Well completion, well perforation intervals and production and injection history, and static pressure have been specified for each individual well (14 wells) included the pseudo wells.

- In the initial condition for the Mishrif Formation, it has used 3900 psi as initial reservoir pressure and $2505 \mathrm{mKB}$ as oil-water contact of the Mishrif Formation.

- The full-field simulation model is considered time-consuming and the sector model used to divide the entire reservoir into small parts and efficient to make the evaluation of water flooding or pressure maintenance of the specific area, in the study, used the conclusion authors (Bruijnzeels and O'Halloran, 1995) to deal with boundary condition by adding additional grid blocks or three-phase tank to the remedied effect of flow around the sector boundary. Several wells have been added to make the realization of the boundary condition of the model in the south boundary, where the sector model has no flow with northern boundary, eastern and western flanks. Consequently, the simulation model of these grid blocks is represented by true reservoir properties (Shamkhi and Aljawad, 2021). The fourteen wells have been identified into black oil simulator (ECLIPSE-100) to validate the output model, which are (WQ1-XX1 to WQ1-XX17) as a producer well except wells (WQ1-XX6, WQ1-XX14, WQ1-XX16, WQ1-XX12) as injector wells, and (WQ1-XX4, WQ1-XX12, WQ1$\mathrm{XX17)}$ as pseudo wells. These wells are obtained the matched historical oil and water production and injection data with static and flowing bottom hole pressure. Fig.16 shows the history matching of the sector for observed and calculated data.

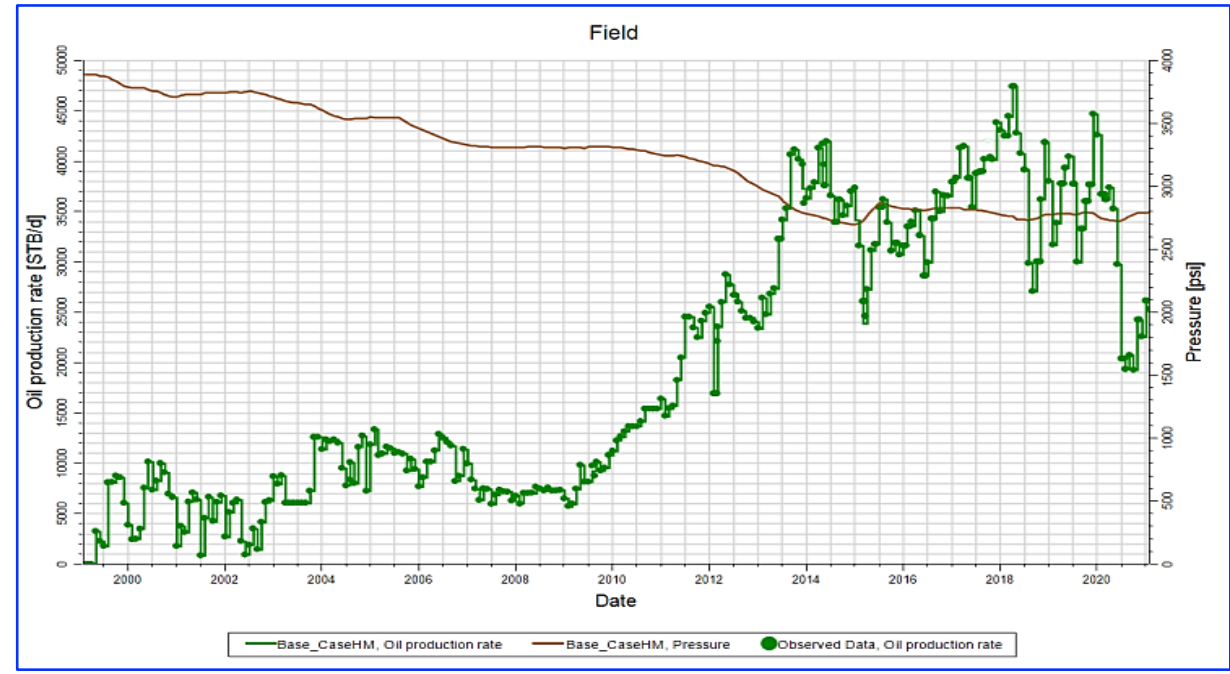

Fig. 16. Sector oil production (observed and calculated) with calculated sector pressure 


\subsection{Model Constraints}

A good history matching was obtained for the sector under study, as shown in Fig. 16. It can be used in the future prediction of field development subsequent to other forecasted sectors to make fullfield prediction performance. The basic constraints for the three proposed water injection patterns are illustrated by the following parameters, which are the production rates from producers are controlled by minimum bottom flowing pressure (BHP $\geq 2200 \mathrm{psi}$ ) which is the bubble point pressure, water injection rate controlled by maximum well bottom pressure that will not exceed the rock fracture pressure, which estimated about 5500 psi for the field under study, and maximum water cut during the development strategies $50 \%$.

\subsubsection{Development strategies}

Both suggested patterns (inverted nine spot-original configurations, five-spot) were applied to improve oil recovery and future sector performance by using simulator-ECLIPSE 100 for eighteen years (from 2020 to the end of 2038). Two main cases have been proposed for each pattern and then subjected each of these cases to optimization rules to minimize the water production as low as possible.

\subsubsection{Inverted Nine-Spot configuration}

Two cases have been implemented, where case $(1 \mathrm{~B}, 1 \mathrm{C})$ was considered the original case depending on the well's alignment in the studied area without changing the locations of injection or production wells. In this case, completion of wells and injection rate. The second case (2B, 2C) used the same input parameters of case $(1 \mathrm{~B}, 1 \mathrm{C})$, case $(2 \mathrm{~B}, 2 \mathrm{C})$ has been subjected to shut off the worst perforation, and plug of some highly water production in the $\mathrm{mB}$ unit, as shown in Fig.17.

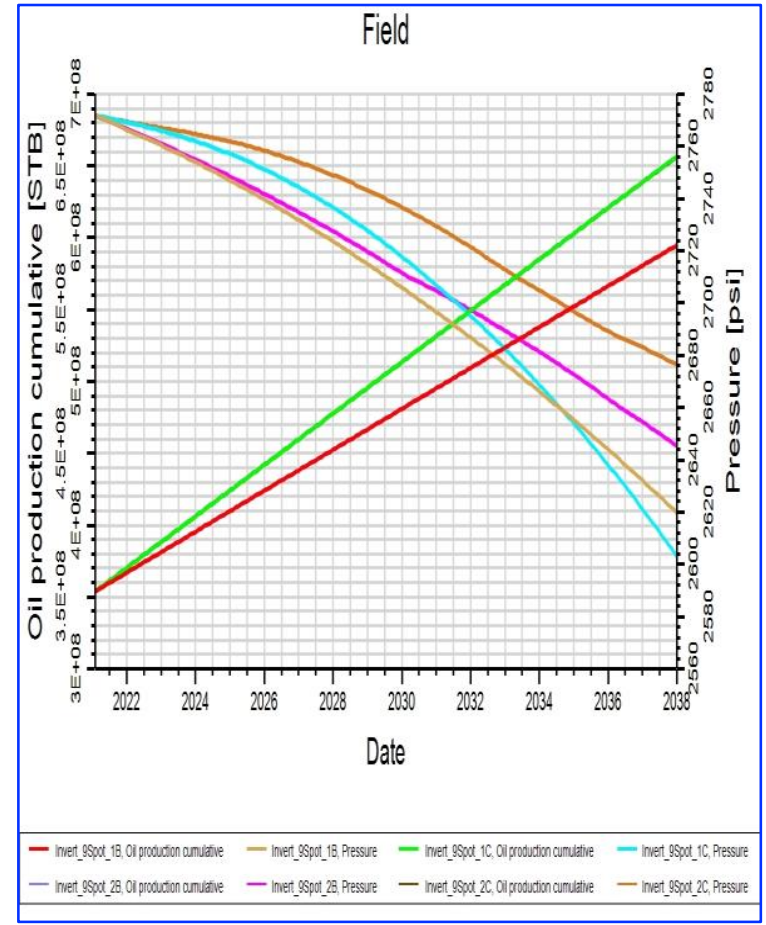

(a)

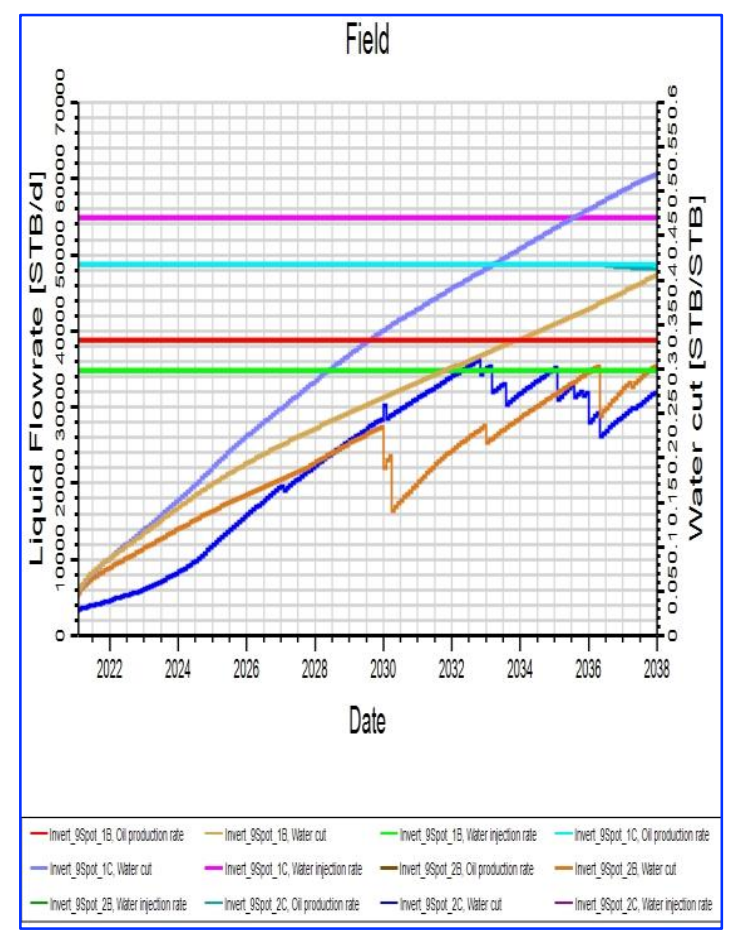

(b)

Fig.17. The development scenarios of 9-spot: (a) shows the cumulative oil production and pressure for cases $(1 \mathrm{~B}, 2 \mathrm{~B}, 1 \mathrm{C}, 2 \mathrm{C})$. (b) Shows the oil production and injection water with water cut for cases (1B,

$2 \mathrm{~B}, 1 \mathrm{C}, 2 \mathrm{C})$ 


\subsubsection{Five-Spot Configuration}

Due to flexibility change of inverted nine-spot configuration to five-spot alignment without drill any additional wells for production and for injection purposes, it has been converted the specific wells to be fit to the five spot alignment, two cases also have been established (1A, 1B) with different oil production and injection targets, and then optimized each case by reducing water production through using shut off plug such as bridge plug and plug the offending perforation and some wells extended the perforations in the mB1 interval to maximize the hydrocarbon recovery, as illustrated in Fig. 18.

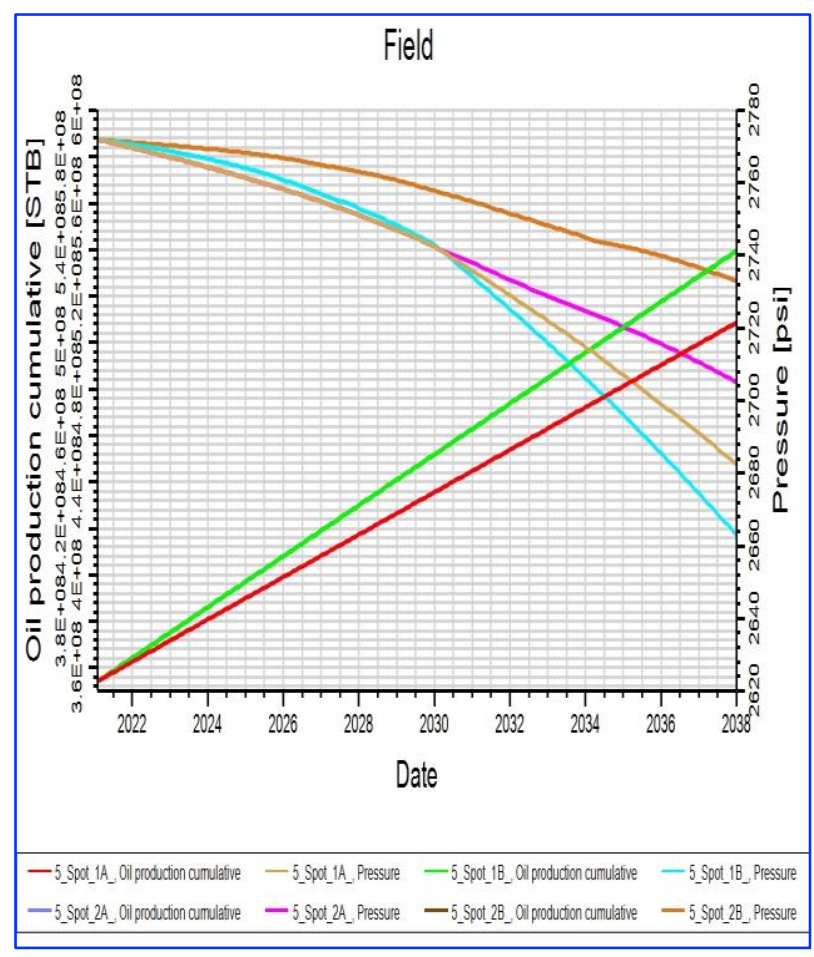

(a)

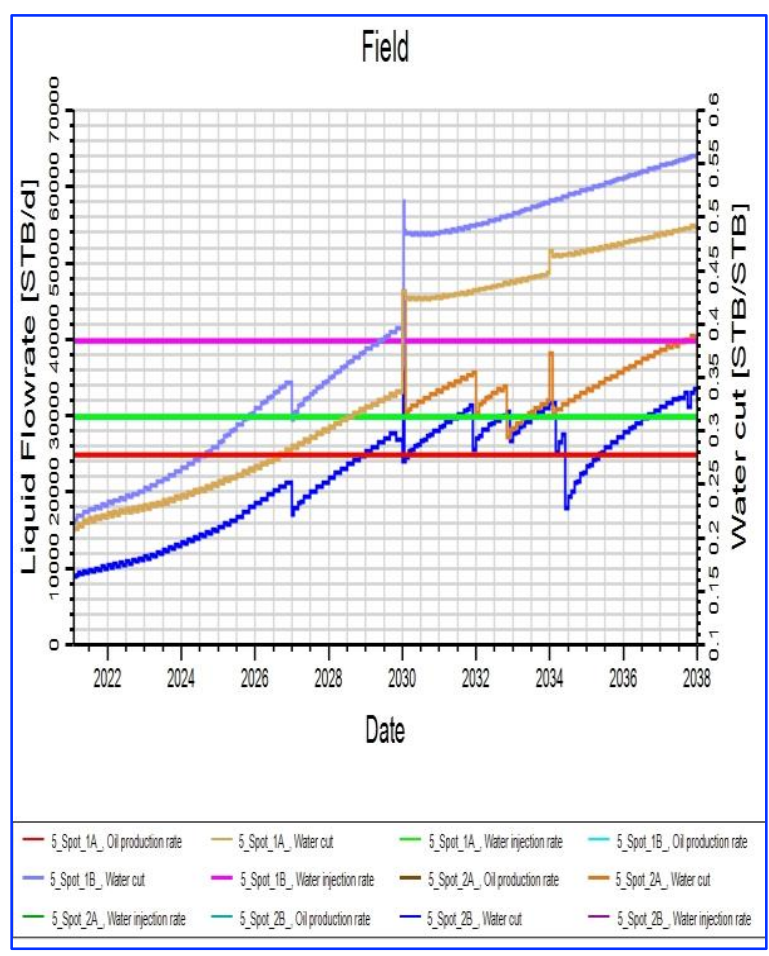

(b)

Fig.18. The development scenario of 5 spot: (a) Shows the cumulative oil production and pressure for cases (1A,2A, 1B,2B). (b) Shows the oil production and injection water with water cut for cases (1A,

$2 \mathrm{~A}, 1 \mathrm{~B}, 2 \mathrm{~B})$

\section{Discussion}

Two patterns were implemented in the development strategies and the outputs as follows:

\subsection{Nine Spot Development Strategy}

- It observed enhancement in pressure drop through prediction strategy after applying optimization to production through minimizing the produced water and result in maintaining the sector pressure. As shown in Fig.17, the pressure of each case was kept above the bubble point pressure but noticed the best-maintained pressure was on the case_2C at the end of the scenario to 2676.6 psi.

- The water cut of each previous case at the end of the prediction scenario, which was not influenced by optimization limits of producing water, ranged within ( $40.5 \%$ to $52.06 \%)$. After managed water production, the water cut ranged within ( $27.5 \%$ to $35.25 \%$ ) which are considered as reasonable values because it examined as an economic measure from a practical view. According to Fig.17, the case_2C is best strategy (49000 STB /D) within the less (WCT) at end of the plateau (27.5\%). 


\subsection{Five Spot Development Strategy}

- There is a pressure drop in the field pressure through the production predicted suggested pattern. After applying optimization to reduce the water cut for efficient strategy, it has been noticed the maintaining pressure in each case with different values, case $2 \mathrm{~B}$ showed the suitable sector pressure maintained in the end scenario to 2720 psi.

- The case 2B as shown in Fig. 18, is the optimal strategy for this pattern (five-spot) because of the constant oil production to the end of the plateau, which is 30000 STB /D with acceptable water cut end of the plateau (34.04\%) for this pattern.

\section{Conclusions}

In this study, a sector simulation model was used in the Mishrif reservoir to review the future performance of a water injection pattern of an interesting area. Due to full-field model is considered time-consuming of data, computational, and processes, a sector model has flexibility that can be beneficial for to adapt the computational time and analysis for a particular model. The boundary condition for the simulated sector was treated by gird block connection based on wells were located. In addition, three wells were added as pseudo wells (injection wells) to obtain the history matching of the model data. The presented capillary pressure, two relative permeability curves, and PVT data were illustrated earlier, and introduced into a model, and gave an acceptable result. During the forecasting strategies of this research, four main cases have been performed, and each case has influenced the optimized water production with high oil recovery. Each plan has obtained the oil production at a constant target with minimum water production. Meanwhile, keep the pressure above the bubble point pressure. It also concluded that Inverted 9-Spot has a reliable to convert to the 5-spot pattern with noticeable slightly decrease of oil production in the five spots than in the nine spots which because of the number of wells involved in the configuration.

\section{Acknowledgements}

The authors are very grateful to the Basra Oil Company for allowing us to use the necessary data to accomplish this study. The authors would like to thank the Petroleum Engineering Department, University of Baghdad. The authors are very grateful to the Editor in Chief Prof. Dr. Salih M. Awadh, the Secretary of Journal, Mr. Samir R. Hijab. And the Technical Editors for their great efforts and valuable comments.

\section{References}

Abbas, L. K. and Mahdi, T. A., 2020. Reservoir modeling of Mishrif Formation in Majnoon oil field, southern Iraq,. Iraqi Geological Journal, 89-101.

Abdullah, R. A., Al-Jorany, K., Mohsin, F., Imad, A., \& Abdulrazaq, M., 2018. Edge water breakthrough in each of the major zones within Mishrif reservoir in West Qurna phase 1. Journal of Petroleum Research \& Studies, (20).

Abdullah, R. A., and Al-Shahwan, M., 2021. Structural geometry analysis of the Khasib Formation in west Qurna I and II supergiant oilfields, southern Iraq. Iraqi Geological Journal, 54(1), 54-66.

Al-Mimar, H.S., Awadh, S.M., Al-Yaseri, A.A. and Yaseen, Z.M., 2018. Sedimentary units-layering system and depositional model of the carbonate Mishrif reservoir in Rumaila oilfield, Southern Iraq. Modeling Earth Systems and Environment, 4(4), 1449-1465.

Al-Mimar, H.S. and Awadh, S.M., 2019. The Role of Chemistry of the Oil-Field Water in the Distribution of Reservoir Pressures: A Case Study of Mishrif Reservoir in the Southern Oil-Fields, Iraq. Journal of Petroleum Research and Studies, 9(1), 52-64. 
Amaefule, J. O., Altunbay, M., Tiab, D., Kersey, D. G., \& Keelan, D. K., 1993. Enhanced reservoir description: using core and log data to identify hydraulic (flow) units and predict permeability in uncored intervals/wells. In SPE annual technical conference and exhibition. OnePetro., 205-220.

Aqrawi, A. A. M., 2013. Sedimentological characterization of the mid-Cretaceous Mishrif reservoir in southern Mesopotamian Basin, Iraq, GeoArabia, 18(1), 139-174.

Avansi, G. D., Maschio, C. and Schiozer, D. J., 2016. Simultaneous history-matching approach by use of reservoircharacterization and reservoir-simulation studies', SPE Reservoir Evaluation \& Engineering, 19(04), 694712.

Awadh, S.M., Al-Mimar, H.S. and Al-Yaseri, A.A., 2018a. Salinity mapping model and brine chemistry of Mishrif reservoir in Basrah oilfields, Southern Iraq. Arabian Journal of Geosciences, 11(18), 1-12.

Awadh, S., Al-Mimar, H. and Al-yaseri, A., 2018b. Potentiometric Salinity Mapping of Mishrif Oilfield Waters in (Iraq's) Southern Oil Fields. In Conference of the Arabian Journal of Geosciences (49-52). Springer, Cham.

Bruijnzeels, C. and O’Halloran, C., 1995. Rabi multi-sector reservoir simulation model', in SPE Reservoir Simulation Symposium. Society of Petroleum Engineers.

Boschetti, T., Awadh, S.M., Al-Mimar, H.S., Iacumin, P., Toscani, L., Selmo, E. and Yaseen, Z.M., 2020. Chemical and isotope composition of the oilfield brines from Mishrif Formation (southern Iraq): Diagenesis and geothermometry. Marine and Petroleum Geology, 122, 104637.

Chen, Z., 2007. Reservoir simulation: mathematical techniques in oil recovery. SIAM.

Dzyuba, V. I., Litvinenko, Y. V., Bogachev, K. Y., Migrasimov, A. R., Semenko, A. E., Khachaturova, E. A., \& Eydinov, D. A., 2012. Application of sector modeling technology for giant reservoir simulations. In SPE Russian Oil and Gas Exploration and Production Technical Conference and Exhibition. OnePetro.

Ezekwe, N., 2010. Petroleum reservoir engineering practice. Pearson Education.

Guyaguler, B. and Horne, R., 2000. Optimization of well placement. Journal Energy Resource Technology, 122(2), 64-70.

Hassler, G. L., and Brunner, E., 1945. Measurement of capillary pressures in small core samples', Transactions of the AIME, 160(01), 114-123.

Lian, P., Ma, C., Ji, B., Duan, T., \& Tan, X., 2017. Numerical simulation modeling of carbonate reservoir based on rock type. Journal of Engineering, 2017.

Mattax, C. C., and Dalton, R. L., 1990. Reservoir simulation, Journal of Petroleum Technology, 42(06), 692-695.

Ogbeiwi, P., Aladeitan, Y. and Udebhulu, D., 2018. An approach to waterflood optimization: case study of the reservoir X', Journal of Petroleum Exploration and Production Technology, 8(1), 271-289.

Pan, Y. and Horne, R. N., 1998. Improved methods for multivariate optimization of field development scheduling and well placement design', in SPE Annual Technical Conference and Exhibition. OnePetro.

Shamkhi, M. K., and Aljawad, M. S., 2021. Representative sector modeling and waterflooding performance in Rumaila Oilfield, Iraqi Journal of Science, 62(1), 192-203.

Tleukhabyluly, O., Dallorto, M., Porcelli, F., \& Tarantini, V., 2016. Speeding up a reservoir simulation, case study on giant carbonate reservoirs. In SPE Annual Caspian Technical Conference \& Exhibition. OnePetro. 